\title{
The Mariel Effect: Deserving Freedom and Other Myths of Exile
}

\author{
Karina Cespedes \\ University of Central Florida, US \\ Karina.Cespedes@ucf.edu
}

This testimonio provides a personal narrative of the overt discrimination endured by Cubans arriving in 1980 and how the term "Marielito" operated to racialize Cubans entering the U.S. during the crisis, thereby distinguishing the newly arrived from previous Cuban exiles who were deemed as more deserving of freedom. This account conveys the ways in which Cubans who were not part of the boatlift, but who instead found themselves in transit to the U.S. during the crisis via different routes were impacted by the crisis in terms of the animosity they faced and having to navigate a state of being in refugee limbo, suspended between nations and communities, ni de aquí, ni de allá.

The overt discrimination endured by Cubans arriving in 1980 was marked along racial, classed, and political lines, and those arriving via Mariel received not only differential treatment but were left unprotected under the newly minted Refugee Act. The difference in reception, both by the Federal government and by the established Cuban community, was utilized to designate the population as undeserving of what Mimi Nguyen has called "the gift of freedom"; an assemblage of liberal political philosophies dependent on regimes of representation and structures of enforcement that measure and manufacture freedom. Utilizing Nguyen's theorization, this personal account addresses the systems that regulate which racialized populations merit freedom and thereby citizenship, and which are considered racially undesirable, their ability to integrate into the nation, and into the community, subsequently called into question. The testimonio intersects the historical impact of Mariel with the contemporary regimes of representation within Cuba designed to designate labor migrants from Oriente to Havana as undeserving of entry.

Keywords: Mariel; race; class; La Virgen de la Caridad; San Lazaro; gift of freedom

\section{Navigating Multiple Worlds...}

My family left Cuba for Spain in February of 1980, two months before the boatlift. In April of that year I turned six just as news of Mariel reached us in Madrid. We heard stories of ten thousand Cubans seeking asylum at the Peruvian embassy in Havana, the organized protests against those clamoring to leave, and the arduous crossing in small, dangerously overcrowded, malfunctioning and ill-equipped boats circuitously navigating the Florida Straits between Miami and Mariel. My parents didn't have to make the heart wrenching decision to leave via Mariel. We had instead traversed a more established route off the island and navigated along with other Cubans the condition of being in refugee limbo-suspended between nations, finding ourselves ni de aquí, ni de allá.

Our journey was marked by waiting. First, we waited in Cuba for a year after our exit date was set, during which time my parents were harassed and expeditiously discharged from their jobs once they made known their intentions to leave. Family and friends distanced themselves; the government issued Libreta de Abastecimiento (food ration booklet) was nulled, leaving my parents with few choices in the midst of what to them felt like an unending food crisis. Once in Madrid we waited again, this time eight months before being permitted safe passage to re-across the Atlantic. At the time I didn't understand Cuba's close geographical proximity to the U.S., nor why such a long and circuitous route between Spain and the U.S. had 
been created. The irony of having to travel to what some term as either la madre patria, or the land of the former colonizer, did not escape my parents-particularly my father. During our eight months in Madrid we shared a cramped three-bedroom apartment with two other Cuban families; each family unit awaiting entry was contained to a bedroom and awkwardly shared a tiny living room and kitchen. To survive in Spain my parents worked and made ends meet with the help of a lose network of other in-transit Cubans patiently waiting U.S. entry.

Whether departing via Mariel or Spain, the population leaving Cuba in the late 1970s was politically, racially, and economically distinct from earlier waves of disaffected Cubans. My father, Celestino, a teenager at the start of the Revolution, was a former political prisoner jailed for six years. He was charged with engaging in counter-revolutionary activity and, as his prison release papers read, was deemed a threat to the nation. His crime had been illegally attempting to escape the island via a small boat and being in possession of firearms when intercepted by the Cuban coast guard. My father, originally from the town of Veguitas in the Oriente province, hailed from a family of color connected to the family of Carlos Manuel de Céspedes as both the descendants of those held in bondage and as unrecognized kin. His family had been active in the anti-colonial war against Spain and by the middle of the twentieth century were solidly middle-class, navigating the particular privileges only available to people of color with means while contending with the severity of Cuban racial segregation. With the onset of the Revolution, his family lost their wealth and all properties except for a small three-bedroom home in Havana. My father was incarcerated as a teenager just as his mother, alongside a large swath of his family, left the island; all the while a few members of the same family rose to positions of prominence within the new government. My mother, María de los Angeles, hails from the small rural town of Máximo Gómez, just outside the small city of Cárdenas, made famous by Elián González. My mother is the granddaughter of white Canary Islanders; her parents held a second-grade education and her father worked as a janitor at the Matanzas Train Station. With the revolution my mother left Máximo Gómez and headed to the University of Havana at the age of seventeen, where she was educated as a doctor.

My parents met in Havana at a bus stop just outside the university. My mother had concluded her classes, while my father, who had just been released from prison, was in the area while reporting to a mandatory employment site located just outside the university. Both were living lives previously unimaginable. Prior to the Revolution, my mother would not have been educated beyond high school; in fact by the age of fifteen most of her cousins were married. My father would have been the one potentially attending the university after graduating from the prestigious Colegio de Belén, a Catholic school where very few boys of color, with connections to prominent white Cuban families, were able to attend what was otherwise an all-white institution. Their pre-Revolutionary worlds, and worldviews, couldn't have been more different, yet what brought them together in the early 1970s had everything to do with how the society had been transformed a decade into the Revolution-they were the victims of some of these changes, and yet the beneficiaries of others. In many ways my parents, similar to many members of their generation who had stayed or found themselves unable to leave Cuba, learned to walk in multiple worlds, assume roles within the society previously unimaginable, and survive dramatic shifts in social status. My mother had never imagined herself able to become a doctor, live as a single woman in Havana, nor come of age during what can be described as Cuba's own form of women's liberation following the Revolution-able to select her own romantic partner, and for that partner to be a man of color. My father had never imagined himself to someday spend years as a political prisoner, and considering the family he hailed from, had never thought possible experiencing a loss of status, much less being branded a threat to the nation. His ancestors after all had been at the forefront of national liberation wielding machetes against the Spanish. Once in Spain, my parents found themselves traveling through yet a new social identity-that of being refugees with young kids in tow, having to "resolver" (make do).

\section{The Day La Caridad and San Lázaro Came to Live with Us...}

I first heard the word Mariel around the time my mother purchased two plaster statues, one of La Virgen de la Caridad and the other of San Lázaro. The look of accomplishment on my mother's face as she unboxed these sibling statues communicated the cultural and religious importance of the pair, and her longing for home. And, once La Caridad and San Lázaro came to live with us in that small apartment in Madrid it felt as if two recently arrived relatives from Cuba joined us just in time to cross the waters again. As I stared, fixated on the plaster representation of the three stranded young men in the small fishing boat at the feet of La Caridad, my mother explained that La Caridad helps those on the small boat safely reach the shore and San Lázaro helps those who are infirmed and ostracized. Looking at La Caridad and los tres Juanes, I wondered how the expressions of affliction and devotion on their faces had been so perfectly captured in plaster as my parents feverishly discussed the crisis of the boatlift unfolding. 
News of Mariel spread like wildfire among the Cubans waiting in Madrid. On the weekends Cubans would congregate at specific parks-where calls to family in Cuba were possible via payphone-and as families took turns making their calls those present engaged in dizzying conversations about what had happened, who was able to leave, who had been separated from their families, and the tales of emotionally wrenching scenes unfolding at the processing site at the port of Mariel were exchanged and simplified for the children listening and asking questions. All made predictions as to who else would leave, and commented on how some, like my uncle José in Havana, were receiving additional access to food and other goods from the government hoping to appease the population, save face as the international media covered the ordeal and aim to avoid a larger exodus that included highly trained segments of the citizenry. Similar to my uncle José, some were additionally incentivized to stay on the island via the use of fear and intimidation. We learned of the fear some felt when my Uncle Cuco left New Jersey, charted a boat in Miami, and headed to Mariel. Uncle Cuco returned to Miami with the boat full of passengers, but without his family who were living in Cuba. He returned emotionally distraught about how his younger brother José and others in the family refused to leave despite the pleading, the explanations, and promises of better outcomes compared to those who did not have direct family sponsorship. They all justified their hesitancy to leave with stories of protestors turning on neighbors, rumors of physical and sexual abuse at the processing site and feeling hopeful that the Cuban government, in light of the crisis, would be forced to change, provide greater freedoms and more access to goods. They feared leaving what was known for what was unknown, feared being associated with la escoria (the undesirables).

\section{Navigating the Mariel Effect...}

Those leaving Cuba were treated poorly before they left the island, and for many that mistreatment continued upon arriving in the U.S. For us, to be new Cuban arrivals in October of 1980 was to be by default similarly considered a social problem. One did not have to cross the Florida Straits as part of the boatlift to be affected by the segregation and discrimination that awaited those who entered via Mariel. Arriving during the era of Mariel to the U.S. meant that it didn't matter that we had left Cuba two months before the boatlift, nor that we entered as had so many pre-Mariel waves of Cuban refugees; instead, and for all intents and purposes, we were part of the Mariel wave of entrants and were regarded with the same suspicions of deviancy and criminality. Usually, fellow cubanos of earlier and more golden migration waves, upon meeting my parents as they looked for work or housing inquired 'when did you arrive?,' as if it were the first question at yet another port of entry. This initial response would soon be followed by a more probing query that sounded less like a question and more like a declaration peppered with disgust in their voices, ¿son marielitos? (are you "Marielitos?"). On various occasions I witnessed my parents stumbling over themselves to quickly respond "no, no, nosotros no..." (no-not us), and as quickly as their words could carry tell their story which began with the words salimos por España (we left through Spain); it was their futile attempt to gain entry to the community and a failed attempt to clean themselves of the "marielito" label. In the end my parents' responses were discounted because my father was still the wrong color and my mother, although white, hailed from the wrong class. Worst of all, in the eyes of longer established Cubans in the U.S., she had been fully educated as a doctor under the regime, which implied her to be a beneficiary of the Cuban revolution, thus an undeserving benefactor of Revolutionary policies that had led to those earlier waves of Cubans going into exile. The fact that she was a young teenage girl when the Revolution happened was insignificant.

The increasingly negative associations that emerged during the boatlift among Cubans, as well as those that circulated among the general U.S. population, made for a challenging transition to life in the U.S. To be called a "marielito" (which was at that time a painfully derogatory term) meant that one would easily be denied housing and employment-but most of all it meant that fellow Cubans, including members of one's family, would distance themselves. The profound and painful differences that had emerged between those that had left earlier, long before Mariel, and those that had stayed behind only to arrive during Mariel played themselves out during the crisis. These differences manifested themselves via the enactment of older, preRevolution forms of Cuban racism, classism, and political mistrust, all of which bubbled up to the surface, and were easily encountered.

The overt discrimination endured by Cubans who arrived in 1980 was clearly marked along racial, classed, and political lines-"marielito" as a term, operated as a way to racialize as well as politically label the new arrivals; it marked and distinguished this new population from the previous exiled community deemed as more deserving of freedom. The ways in which those arriving via Mariel were left unprotected under the newly minted Refugee Act - which did not extend Federal funding and assistance to the Mariel entrants signaled to the Cuban community in the U.S. that this population was not like them, and unmeritorious. 
The difference in reception both by the Federal government and by the established Cuban community was utilized to designate the population as undeserving, not made of "the right stuff," thus not meriting what Mimi Nguyen describes as "the gift of freedom." This "gift of freedom" is an assemblage of liberal political philosophies; it relies on regimes of representation, and structures of enforcement that measure and manufacture freedom-and its others. Nguyen's theorization assists in naming the systems that regulate which racialized populations merit freedom and thereby citizenship and which are considered racially undesirable - their ability to integrate into the nation, and into the community, of course, called into question.

In terms of the regime of representations that created the "marielito" as a social liability racialized criminal and queer threat-a prime observable example is the moral panic that emerged around boats full of the mentally ill, prisoners, and homosexuals being purposefully sent by Castro. It was as if the exiled community failed to apply to those arriving via Mariel the useful narratives of oppression that fueled their own status as meritorious refugees who had endured, like my father, prison sentences for political dissent, or like my mother, had suffered great mental distress and persecution based on religious and other identities. When it came to Mariel many forgot that the prisoners were potentially political, and the 'unwanted' were persecuted for their respective religious and sexual identities. For the established exiled community these new arrivals threatened the carefully constructed narrative that Cubans refugees were white noble victims of communism, meritorious of "the gift of freedom" provided by the U.S.

\section{When Did the Term "Marielito" Become OK?}

Decades after the boatlift the term "marielitos" circulates less as a derogatory slur and more as something akin to an identity category, and some may argue that the term has been "recuperated," but for me, to this day the term is painfully charged. When I'm among Cubans, and I say that I arrived in 1980, the statement still raises an eyebrow-and often I receive a knowing, Oh, el ochenta (oh, 1980). If by chance they know I'm a university professor I can read in their faces, "oh, you must be a marielita, and even though you came in 1980 you did ok, you got an education," as if it is a miracle that I outperformed my group, the presumed disfunction and assumed deviancy. Often, because I know well the power of the stigma within the community, I don't bother to follow-up with any information about my family arriving through Spain in 1980. As an adult I don't avoid the association with Mariel, but this is not out of a sense of "recuperation"-this is born out of an acknowledgment that my presence and experiences within this community are marked by the racism, classism, political conservatism, and homophobia that sits at the core of cubanía en el exilio.

\section{San Lázaro Helps Those Ostracized}

To add to the complexity of it all-Cubans on the island have held on to the perception that those who left in 1980 were deviants as well. For example, over the course of the last two decades I have been writing about contemporary Cuba-and this has resulted in various trips to the island, where on one occasion a woman working at a Havana cigar factory I was touring as part of my research learned I was Cuban and asked me what year I had left; on hearing 1980 she responded without skipping a beat, "ioh! la escoria que se fue de aqui en el 80 !" (oh, the trash that left in 1980!). Her response was meant to be hurtful, perhaps to raise her discontent about the privileges that those who left in 1980 or earlier, previously seen as traitors and "scum," now entered Cuba with great economic influence. This encounter left me speechless, hyperaware of all my privileges as I found myself refusing to say, ino, yo no! nosotros salimos por España (no, not I, we left via Spain). Instead, I said nothing and started to cry much like I did the day I left Cuba. As I cried I quickly fled the factory; I didn't look to see if her face showed remorse or whether it revealed feeling justified and pridefully satisfied with herself. I simply cried, overwhelmed by the absurdity of it all. Ultimately, this woman's response would prove instructive as to the ways in which othering functions like a cancer and turns a community on itself fueling greater conflict and division-and it revealed the deep social insecurities that ail the population.

Seeking to understand the impact of the feverous rage that turns the community in on itself I have for many years dedicated areas of my research to writing about unequal social relations in Havana, and in particular how Cubans from the eastern provinces of Oriente, the area my father is from, have migrated into western regions over the last two decades seeking greater access and opportunities. These internal labor migrants, also referred to as "escoria" (scum), have been derogatorily named palestinos (Palestinians); many live as undocumented internal labor migrants prone to food insecurity and exploitation. These internal laborers migrating from the eastern regions of the island are openly discriminated against, treated as 
undeserving "foreigners" in their own country. Often, I've been struck by how orientales residing in the western regions of the island endure similar forms of disdain from habaneros as did those who entered the U.S. via Mariel.

The scapegoating, ostracizing, and rejection of these populations fit classic manifestations of racism and classism expressed as regionalism. Within the communist context of Cuba these are communicated via representations and discourses that construct easterners as foreigners/ "palestinos" with lower nivel de educación (level of education). Here, education level becomes code for racial and cultural difference. The preoccupations and scapegoating I have witnessed via my research in Havana and in Miami reveal the complex precariousness of the receiving communities, which although by all appearances hold more powerful positions within the society compared to their newly arrived compatriots, are none the less experiencing scarcity and insecurities that include fearing not being able to control and shape cultural capital, dread over being racialized outside of notions of whiteness, consequently loosing access to economic and political power.

If we consider the similarities between Miami and Havana, the scapegoating of racialized others within the community speaks volumes about the precariousness of Cuban whiteness within the U.S. as well as within global circuits of power investing in Cuba. Studying how Miami and other cities with large Cuban populations emerged before Mariel as centers of economic, political and cultural power for Cubans-how Cubans in the U.S. had amassed wealth and prosperity via Federal assistance programs as well as social acceptance based on notions of whiteness extended to Cubans - and then similarly contrasting how within the context of Cuba, Havana is the center of political and cultural power, then the fear of being 'taken over' by populations deemed as "undeserving" can be seen as interconnected with the fear of not being seen as "white". The loss of "whiteness" within the U.S. context of the 1980s translated for the Cuban exile community into real economic and political losses. Likewise, in Havana the influx of orientales that spans multiple decades into what is Cuba's cultural and political center of power is threatening to Havana residents concerned over labor competition, scarcity of goods, and loss of the currency of whiteness among regional, hemispheric, and global powerbrokers. In both cases the anti-blackness reveals the community's unexamined anxieties. It also reveals the necessity to ask ourselves different kinds of questions, beginning with, how do we approach healing these internal conflicts and reach an understanding where, despite any one particular crisis, we do not turn against or abandon one another in moments of need? How can we, to borrow what Lillian Manzor shared with me via personal correspondence, make possible reflecting on and resolving the multiple ways that Cubans are fractured along generational, regional, racial, political, ideological, and class lines?

\section{Competing Interests}

The authors have no competing interests to declare.

\section{Reference}

Nguyen, Mimi. The Gift of Freedom: War, Debt, and Other Refugee Passages. Duke UP, 2012. DOI: https://doi. org/10.2307/j.ctv1220ns7

\footnotetext{
How to cite this article: Cespedes, K 2021 The Mariel Effect: Deserving Freedom and Other Myths of Exile. Anthurium, 17(2): 15, 1-5. DOI: https://doi.org/10.33596/anth.471
}

Published: 14 December 2021

Copyright: (c) 2021 The Author(s). This is an open-access article distributed under the terms of the Creative Commons Attribution 4.0 International License (CC-BY 4.0), which permits unrestricted use, distribution, and reproduction in any medium, provided the original author and source are credited. See http://creativecommons.org/licenses/by/4.0/. 